УДК 811.161.2’373.231(477.83)

DOI https://doi.org/10.26661/2414-9594-2020-2-21

\title{
ДИНАМІКА ОСОБОВИХ ІМЕН РАДЕХІВСЬКОГО РАЙОНУ ЛЬВІВСЬКОЇ ОБЛАСТІ
}

\author{
Христіанінова Р. 0. \\ доктор філологічних наук, професор, \\ завідувач кафедри украӥнської мови \\ Запорізький національний університет \\ вул. Жуковського, 66, Запоріжжя, Украӥна \\ orcid.org/0000-0002-0045-1026 \\ khrystianinova@gmail.com \\ Омельковець Р. С. \\ кандидат філологічних наук, \\ дочент кафедри історії та культури української мови \\ Волинський національний університет імені Лесі Украӥнки \\ пр. Волі, 13, Луцьк, Україна \\ orcid.org/0000-0001-6608-7901 \\ omelkovets.ruslana@eenu.edu.ua
}

\begin{abstract}
Ключові слова: антропонім, іменник, онім, чоловіче ім'я, жіноче ім'я, частотні імена, рідковживані імена, поодинокі імена.
\end{abstract}

У статті на матеріалі антропонімікону Радехівського району Львівської області простежено динаміку чоловічих та жіночих імен з 1970 р. до 2020 р. Окреслено склад жіночого та чоловічого іменника́ зазначеного району, здійснено його якісний та кількісний аналіз, зокрема визначено частотні, маловживані та поодинокі імена на шести зрізах, кожен з яких охоплює десятиріччя, що дало змогу визначити найуживаніші імена в кожному десятиріччі і впродовж шістдесяти років загалом, стрижень стабільних імен, зміни в наборі найуживаніших імен, збереження класичних і появу нових імен, частотність уживання онімів. Указано причини, що впливали на оновлення й розширення асортименту найуживаніших імен.

Упродовж останніх десятирічь ХХ ст. (з 1970 р. до 2000 р.) у чоловічому та жіночому антропоніміконі Радехівського району Львівської області засвідчено відносну консервативність у виборі імен для хлопчиків і дівчаток та своєрідну певну прерогативу, що іiі надають деяким іменам. Новонароджених називають переважно в честь дідусів, батьків, бабусь, матерів та інших шанованих членів родини. Для цього періоду характерний постійний і компактний набір лексем, який складається виключно 3 традиційних, рекомендованих церковними святцями календарних імен. Спостережено значну концентрацію імен, тобто невелика кількість їх охоплює більшу частину новонароджених.

У XXI ст. ситуація вибору імен змінилася. 3 початку століття спостережено значне оновлення й розширення асортименту як чоловічих, так і жіночих імен. Установлено, що на перший план під час називання народжених дітей у цей період виходять індивідуальні уподобання батьків, а основним мотивом іменування стає мода на імена, яка дала поштовх до формування вузького кола ультрамодних чоловічих та жіночих імен і виведення 3 обігу багатьох традиційних антропонімів, що змістилися 3 центральної в периферійну зону іменника. До найяскравіших новин в антропонімії цього часу уналежнюємо численні запозичення та багатокомпонентні лексеми, що набули документальної сили. 


\title{
PERSONAL NAMES DYNAMICS: CASE STUDY OF RADEKHIV DISTRICT OF LVIV REGION
}

\author{
Khrystianinova R. O. \\ Doctor of Philological Sciences, Professor, \\ Head of the Department of Ukrainian Movies \\ Zaporizhzhia National University \\ Zhukovskoho str, 66, Zaporizhzhia, Ukraine \\ orcid.org/0000-0002-0045-1026 \\ khrystianinova@gmail.com \\ Omelkovets R. S. \\ Candidate of Philological Sciences, \\ Associate Professor at the Department of History and Culture of the Ukrainian Language \\ Lesya Ukrainka Volyn National University \\ Voli ave., 13, Lutsk, Ukraine \\ orcid.org/0000-0001-6608-7901 \\ omelkovets.ruslana@eenu.edu.ua
}

Key words: anthroponym, noun, onym, male name, female name, frequent names, commonly used names, unique names.
The article considers the issue of male and female names dynamics on the anthroponymic material of the Radekhiv district, Lviv region, within the period of 1970-2020. The study has revealed the specific weight of each of these statistic groups in the highlighted periods. The research findings have provided grounds to determine the most commonly used names in the studied fifty-year period, the core of stable names, changes in the set of commonly used names, the preservation of classic and the emergence of new names, the frequency of onyms use in six sections. The article substantiates the reasons that influenced the update and expansion of the commonly used names range. The analysis of the changes that occurred in the period from 1970 to 2020 in the male and female anthroponymicon of Radekhiv district of Lviv region shows that there existed noticeable conservatism in the choice of names for boys and girls and predisposition to some names. A constant and compact set of names is characteristic of this period. In addition, the study has revealed a significant concentration of names - a small number of them were given to most newborns. Such phenomenon as standardization has become widespread. But, since the beginning of the 21st century, we have recorded the renewal and expansion of the range of both male and female names. The traditional names were in their majority in the anthroponymic system of Radekhiv district of Lviv region until 2000. But family traditions are organically connected with the individual preferences and fashion for names. This factor has become the main motivator of choosing a name and stimulated the formation of a narrowed group of trendy male and female names and caused the withdrawal from circulation of many anthroponyms that occupied positions in the peripheral part of the noun.

The situation with choosing names has significantly changed in the 21 st century. The most striking innovations in the anthroponymy of this time are, without any doubt, numerous borrowings, multi-component tokens that have gained documentary power. 
Постановка проблеми. Цінним елементом культури будь-якого народу є власні імена. Вони здавна привертали увагу представників різних наук. Основоположник антропоніміки в Україні Іван Франко у праці «Причинки до української ономастики» наголошував на тому, що особові назви $\epsilon$ матеріалом дослідження як для філолога, так і для історика та етнографа [1, с. 391]. Але українська ономастична лексика, яку можна розглядати крізь призму історії українського народу, - це насамперед об' єкт уваги мовознавців, адже будь-яке ім'я це слово. Отже, ім'я як знак, на основі якого індивідуалізують та ідентифікують особу, вивчають переважно як мовне явище в його лінгвістичному та історичному розвитку [2, с. 129].

Мотиви іменування бувають різні. У них захований спосіб мислення народу, його психологія й погляди на світ. Основним мотивом вибору імені для немовлят вважають родинну традицію надання синові імені батька або діда. 3 одного боку, це давній звичай обов'язкового продовження хлопчиками батьківського роду, адже в такий спосіб зберігається пам'ять про рідних, а з іншого - родинні традиції впливають на певну консервацію іменника́, стримують наплив свіжих імен i, отже, не сприяють збагаченню іменного репертуару. Проти родинної традиції в іменуванні виступають деякі вчені, котрі досліджують зв'язок особових імен із характером людини. Мотивація їхнього ставлення поринає в галузь психології. Наприклад, професор Б.Ю. Хигір наголошує, що давати синам ім'я на честь батьків, скажімо, на честь батька, небажано, оскільки це може спровокувати розвиток негативних рис характеру, зокрема неврівноваженості, дратівливості тощо [3].

3 позиції філософії імена характеризує визначний учений, філософ П.А. Флоренський [4]. Важливе місце, на його думку, посідає запозичення імен: імена запозичують, перекладають, вони підлягають аррадикації, морфологічним змінам - і так набувають нового вигляду, в більшості випадків дуже далекого від первинного.

У наш час вибір імені є юридично вільним i в усіх випадках залежить винятково від волі найменувачів, тобто батьків. Основні фактори, які посприяли популярності того чи того імені у ХX столітті:

- милозвучність імені (батьки дають дитині приємне, милозвучне ім'я, яке подобається (суб'єктивний фактор));

- релігійний фактор (вибираючи ім'я, користуються церковним календарем i називають дитину іменем того святого, на день якого дитина 3'явилася на світ;

- збереження сімейних традицій (найменування новонародженого на честь батька, дідуся, близького родича;
- «фактор моди», який «підносить» те чи те ім'я в певний період.

Дослідження антропонімії - важлива і цікава проблема сучасного мовознавства, яка потребує всебічного мовознавчого студіювання. Натепер вивчено склад і динаміку імен протягом значного часового проміжку на антропонімійному матеріалі окремих регіонів України: Буковини (Л.В. Кракалія, Л.В. Чувашова), Лемківщини (С.С. Панцьо), Одещини (Ю.О. Карпенко, О.Ю. Касім, ОЮ. Медведєва, Л.П. Зайчикова, С.Л. Брайченко), Волині (І.Д. Скорук), Закарпаття (П.П. Чучка, Л.О. Белей), Тернопілля (Г.В. Бачинська, Н.О. Свистун), Донеччини (Г.В. Кравченко, Т.В. Буга), Кропивницького (О.В. Чорноус) тощо. Однак імена певних регіонів усе ще мало досліджені. На думку П.П. Чучки, успішне вивчення національного іменника́ неможливе без докладного аналізу регіональних антропонімійних систем та їхніх структурних елементів так само, як неможливе успішне дослідження загальнонаціональної мовної системи без належного вивчення діалектів [5, с.14]. Дотепер поза увагою мовознавців був антропонімікон Радехівського району Львівської області, тому вивчення його складу та динаміки вкрай актуальне.

Метою статті $\epsilon$ аналіз жіночих та чоловічих імен указаного району в динаміці за період із 1970 p. до 2020 р. Завдання дослідження полягає в тому, щоб окреслити склад жіночого та чоловічого іменника́ Радехівського району Львівської області, здійснити його якісний та кількісний аналіз, зокрема визначити частотні, маловживані та поодинокі імена. Матеріалом дослідження послугували чоловічі та жіночі імена жителів Радехівського району Львівської області. У межах указаного хронологічного періоду розмежовано 6 десятирічних зрізів.

Матеріал і методи дослідження. Джерельною базою роботи слугували дані Головного управління статистики у Львівській області.

Поставлена мета та специфіка досліджуваного матеріалу зумовили застосування дослідницьких методів, які відповідають лінгвістичному і специфічно антропонімійному аспектам: описового, статистичного, зіставного й експериментального.

За розмежування імен на частотні й рідковживані ми користуємося реальними цифрами, які орієнтовані на відносні, а не на абсолютні величини кількості носіїв. Так, з певною долею умовності, імена, рівень активності яких перевищує або становить $1,0 \%$, ми кваліфікуємо як частотні, решту імен (до $1,0 \%$ ) - як рідковживані. Це спрощує методику опису антропонімійного матеріалу, робить ii логічнішою і стрункішою, забезпечує якість виявлення динаміки досліджуваних іменникі́в. 
Частотність окремого імені, виражена у відсотках, - це доля новонароджених із таким іменем відносно всіх новонароджених відповідної статі впродовж визначеного зрізу. Частотність імені визначаємо як відношення кількості новонароджених, що дістали таке ім'я, до загальної кількості новонароджених цієї статі, прийнятої за 100\%.

Виклад основного матеріалу дослідження. Аналізуючи динаміку чоловічого та жіночого антропонімікону Радехівського району Львівської області впродовж досліджуваного періоду, виокремимо такі основні іiі риси:

1) відносну консервативність у виборі імен для хлопчиків і дівчаток (період із 1970 р. до 2000 р. характеризується відносно постійним і компактним набором імен);

2) своєрідну прерогативу деяких імен (окремі імена протягом усього аналізованого періоду залишаються в списку найчастотніших);

3) значну концентрацію імен (невелика кількість їх охоплює переважну більшість новонароджених);

Водночас наголосимо, що попри названі тенденції, що забезпечують стабільність імен, 3 початку XXI ст. все-таки фіксуємо оновлення й розширення асортименту як чоловічих, так і жіночих імен.

\section{1. Чоловічий іменник}

У 1970 р. як найбільш частотне чоловіче ім'я зафіксовано онім Володимир (14,9\%), друге місце за вживаністю посідає онім Василь (11,9\%), третє місце розподілили між собою імена Андрій та Ігор $(9,8 \%)$. Трохи поступаються зазначеним оніми Роман $(7,7 \%)$ та Іван (5,6\%). А імена Юрій $(4,1 \%)$, Микола, Олег, Петро (3,6\%), Богдан, Тарас (2,6\%), Михайло, Степан, Григорій (2,1\%), Йосиф, Олександр, Сергій, Ростислав, Ярослав, Орест (1,5\%) та Віктор (1\%) вживані значно рідше, хоча так само зараховані до частотних на досліджуваній території, оскільки набирають більше $1 \%$. Рідковживаними чоловічими іменами в 1970 р. в Радехівському районі можна вважати такі: Biталій, Костянтин, Леонід, Любомир, Павло, Жорж та Альберт, вони набирають менше ніж по $1 \%$.

У 1980 р. значної переорієнтації поглядів на чоловічі імена не відбулося, адже пріоритетним так і залишилося ім'я Володимир (17,5\%), проте другу позицію посідають уже імена Андрій $(12,7 \%)$ і Роман (10,8\%), частотність використання яких зросла відповідно на 2,9\% і 3,1\%. Онім Ігор залишився на третьому місці, хоча частотність його вживання знизилася на $2 \%$ і становить $7,8 \%$. Із другого на третє місце змістився онім Василь, який втратив $4,1 \%$, частотність його використання в цей період така сама, як і імені Ігор. Фіксуємо й деякі інші імена, частотність яких зросла порівняно з попереднім періодом, зокрема це Юрій - 6\% проти 4,1\%, Олег - 4,8\% проти 3,6\%, Михайло - 3\% проти 2,1\%, Сергій - 2,4\% проти $1,5 \%$, Олександр - 1,8\% проти $1,5 \%$, Віктор - 1,2\% проти $1,0 \%$; натомість частотність використання окремих онімів зменшилась: Микола - 3\% проти 3,6\%, Іван - 2,4\% проти $5,6 \%$, Степан - 1,8\% проти 2,1\%, Тарас - 1,8\% проти 2,6\%, Петро - 1,8\% проти 3,6\%, Ярослав - 1,2\% проти 1,5\%. До шерегу рідковживаних перейшли частотні в попередньому періоді імена Богдан, Григорій, Йосиф, Ростислав та Орест, водночас до списку частотних у 1980 р. увіходять імена Віталій (3\%) і Любомир $(1,8 \%)$, які в попередньому періоді були рідковживаними.

У 1990 р. зростає популярність оніма Василь, частотність уживання якого тепер становить $13,2 \%$ проти $11,9 \%$ в 1970 р. та 7,8\% в 1980 р. Цей онім посідає за вживаністю перше місце з-поміж усіх інших. Друге місце продовжує утримувати ім'я Андрій $(11,4 \%)$, хоч воно й утратило $1,3 \%$ порівняно з 1980 р. Рідше почали називати хлопчиків ім'ям Володимир $(9,6 \%)$, котре раніше було найчастотнішим, натомість набуває популярності рідковживане в попередні два періоди ім'я Назаpiŭ $(9,6 \%)$. Обидва названі оніми посідають третю сходинку в рейтингу популярності. Зростає порівняно 3 минулими періодами частота вживання імен Тарас (7\% проти $1,8 \%$ в 1980 р. та $2,6 \%$ в 1970 р.) і Михайло (3,5\% проти 3\% в 1980 р. та 2,1\% в 1970 р.). Знову набувають популярності такі імена, як: Іван (3,5\%), яке втратило в частоті використання в 1980 р. порівняно 31970 р. (частотність була відповідно 2,4\% і 5,6\%); Богдан (4,4\%), Йосиф (2,6\%), котрі в 1970 р. набирали відповідно 2,6\% і 1,5\%, а в 1980 р. перейшли до низки рідковживаних. На рівні попереднього періоду залишається частотність використання імені Степан (1,8\%). Трохи рідше в 1990 р. називають хлопчиків онімом Віталій, який увійшов до частотних у 1980 p., тепер частотність цього оніма становить $2,6 \%$ проти $3 \%$ у попередній період. Натомість спадає популярність імен Роман (7\% проти $10,8 \%$ в 1980 р. та 7,7\% в 1970 р.), Олег (3,5\% проти 4,8\% в 1980 р. та 3,6\% в 1970 р.), Ігор (2,6\% проти 7,8\% в 1980 р. та 9,8\% в 1970 р.), Юрій (2,6\% проти 6,0\% у 1980 р. і 4,1\% в 1970 р.), Микола (1,8\% проти 3\% у 1980 р. і 3,6\% в 1970 р.). У 1990 р. потрапляють до низки частотних імена Артем, Дмитро і Максим, відсоток використання кожного з них становить 1,8 . До рідковживаних у цей період імен зараховуємо оніми Віктор, Любомир, Олександр, Петро, Сергій, Ярослав (частотність кожного менше ніж $1 \%$ ).

У 2000 р. ім'я Володимир знову набирає популярності та повертається на перше місце за частотністю використання, яка становить 9,5\%. Другу позицію посідає ім'я Богдан $(7,4 \%)$, котре 
збільшило свою популярність на $3 \%$ порівняно 3 попереднім періодом, а третю - Назарій і Андрій $(6,3 \%)$, що втратили в частотності відповідно на $3,3 \%$ та $5,1 \%$ порівняно з 1990 р. Продовжує зростати популярність імен Максим (5,3\% проти $1,8 \%$ в 1990 р.), Юрій (5,3\% проти 2,6\% в 1990 р.), Олег (5,3\% проти $3,5 \%$ в 1990 р.), Іван $(4,2 \%$ проти 3,5\% в 1990 р.), Дмитро (2,1\% проти 1,8\% в 1990 р.), Віталій (3,2\% проти 2,6\% в 1990 р.), Микола (2,1\% проти 1,8\% в 1990 р.). Повертаються до низки частотних імена Віктор та Олександр (4,2\%), Сергій (2,1\%), Любомир (4,2\%), які в попередньому періоді перейшли до розряду рідковживаних. Натомість декотрі імена втрачають популярність, їх використовують для називання хлопчиків рідше, ніж у попередніх періодах, зокрема це Роман (3,2\% проти 7,0\% у 1990 р.), Василь (3,2\% проти 13,2\% в 1990 р.), Тарас (3,2\% проти 7,0\% у 1990 р.). Водночас до списку частотних у 2000 р. увіходять рідковживані в попередніх періодах імена Вадим і Владислав (3,2\%), Свген і Денис (2,1\%). До рідковживаних потрапляє популярне в попередні періоди ім'я Михайло (менше ніж $1 \%$ в 2000 р. проти $2,1 \%$ в 1970 р., 3,0\% в 1980 p., 3,5\% в 1990 р.).

2010 р. став переломним у називанні осіб чоловічої статі. Найуживанішим тепер є ім'я Максим, яке стрімко набирало популярності з 1990 р. (1,8\% в 1990 р., 5,3\% в 2000 p., 11,8\% в 2010 р.). Значно зросла популярність імені Владислав (10,3\% проти $3,2 \%$ у 2000 р.), воно тепер піднялося на друге місце в рейтингу популярності. На третьому місці онім Богдан, який хоч і добавив $1,8 \%$ популярності $(8,8 \%$ проти $7,4 \%$ в 2000 р.), але змістився на щабель нижче. Набирають також популярності імена Олександр $(1,5 \%$ в 1970 р., 1,8\% в 1980 р., $4,2 \%$ в 2000 p., 7,4\% в 2010 р.), Денис (2,1\% в 2000 p., 4,4\% в 2010 p.), Сергій (1,5\% в 1970 p., 2,4\% в 1980 p., 2,1\% в 2000 p., 4,4\% в 2010 p). Частотними залишаються оніми Віталій (3,0\% в 1980 р., $2,6 \%$ в 1990 p., 3,2\% в 2000 p., 2,2\% в 2010 p), Юрій $(4,1 \%$ в 1970 p., $6,0 \%$ в 1980 p., 2,6\% в 1990 p., $5,3 \%$ в 2000 р., 2,2\% в 2010 р.), Михайло (2,1\% в 1970 р., $3,0 \%$ в 1980 p., 3,5\% в 1990 р., 2,2\% в 2010 р). До списку частотних увіходять рідковживані в попередні періоди оніми Ocman (5,9\%), Артур, Станіслав, Ілля та Олексій (2,2\%). Натомість значно втрачають у рейтингу популярності імена Володимир $(14,9 \%$ в 1970 p., $17,5 \%$ в 1980 p., 9,6\% в 1990 p., 9,5\% в 2000 р., 2,2\% в 2010 р.) та Назарій $(9,6 \%$ в 1990 р., 6,3\% в 2000 р., 2,2\% в 2010 р.), а оніми Андрій, Вадим, Василь, Віктор, Дмитро, Євген, Іван, Любомир, Микола, Олег, Роман, Тарас стають у 2010 р. рідковживаними.

Подружні пари, шукаючи щось унікальне, нове, свіже, бажаючи назвати дитину нетрадиційним, рідкісним іменем, звертаються до запо- зичень або ж шукають якісь особливі оніми. Ïх надходження не заважає існуванню традиційних імен. На думку вчених, «наявність тих та інших в антропоніміконі шліфує нові імена, які асимілюються 3 іменними системами сучасної мови» $[6$, с. 21$]$. Б. Антоненко-Давидович розцінює захоплення іменами іншомовного народу як своєрідну моду, якоюсь мірою схожу «з так званим стиляжництвом», і покладає великі надії на широке використання українських імен [7, с. 61]. Зокрема, злам XX-XXI ст. ознаменувався появою в антропоніміконі району милозвучного слов'янського імені Яромир, запозичених Давид, Зеновій, Сільвестр, Маркіян, зміною форми деяких традиційних імен - Назар змінюється на Назарій, а Арсен набирає форми Арсеній.

Крім того, варто зазначити, що в статусі рідковживаних до нового тисячоліття перейшли лексеми слов'янського походження Всеволод, Мирослав, Ростислав, Святослав, Ярослав. Доволі низьку ï популярність О.В. Суперанська пояснює багатовіковим призвичаєнням до того, що імена не повинні щось означати, що «вони створені $з$ елементів запозичених слів» $[8$, с. 115]. Проте дані дослідження А.А. Белецького прогнозують розширення популярності цих імен у майбутньому «через відсутність заперечень із точки зору звукової форми» [9, с. 26].

У 2020 р. найпоширенішими іменами хлопчиків стають Денис, Захар, Матвій, Олексій, Станіслав. А оніми Василь, Михайло, Іван, Мартин, Микола, Нестор, Ocтап, Ростислав уналежнюємо до рідковживаних.

Група одиничних імен упродовж 1970-2020 pp. укомплектована 49-ю лексемами. У 1970 р. та 1980 р. всього по одному разу були зафіксовані оніми Вimaлій, Альберт, Жорж, Костянтин, Леонід, Павло. У 1980 р. наведене коло одиничних чоловічих онімів розширюється іменами Анатолій, Богдан, Григорій, Дмитро, Свген, Зеновій, Ілля, Мар'ян, Мирон, Олексій, Ростислав, Сільвестр. 1990 р. змінює пріоритети - одиничними постають імена Віктор, Любомир, Олександр, Петро, Станіслав, Ярослав. Серед одиничних залишається і Євген. У 2000 р. поодиноко трапляються чоловічі оніми: Антон, Маркіян, Олексій, Орест, Павло, Станіслав, Яромир, Ярослав. У 2010 р. та 2020 р. до одиничних онімів, якими називали немовлят-хлопчиків, зараховуємо: Арсеній, Артем, Василь, Віктор, Гнат, Давид, Данило, Дмитро, Свген, Захарій, Іван, Любомир, Микола, Ярема.

Варто також зазначити, що аналіз досліджуваного угруповання засвідчив поодиноке використання лексем, які є традиційними для іменника́ сучасних європейських мов і ультрамодними в Україні - Даніель (замість узвичаєного для українців Данило), Сільвестр. 
Отже, в 1970-2010 рр. для йменування народжених хлопчиків у Радехівському районі найчастіше вибирали імена: Володимир, Андрій, Ігор, Василь, Роман, Михайло. Серед рідковживаних фіксуємо: Федір, Олексій, Євген, Любомир та Маркіян. Упродовж останнього десятиліття динаміка онімів значно змінилася, і вже у 2020 р. найпоширенішими іменами хлопчиків стали Олексій, Денис, Станіслав, Матвій, Захар.

\section{2. Жіночий іменник}

У 1970 р. в Радехівському районі найпоширенішим жіночим ім'ям було Оксана $(14,0 \%)$. У попередньому десятиріччі воно було найуживанішим лише в м. Луцьку [10, с. 83]. На нашу думку, зростання питомої ваги цього імені вмотивоване модою, яка в різні періоди виявляється по-різному і стрімко піднімає на чільні місця в іменнику́ то ті, то ті імена. Другу позицію посідає онім Марія $(11,1 \%)$, а третю - Галина $(9,9 \%)$. До групи поширених жіночих імен, крім названих, у цей період належать також: Любов (8,8\%), Наталія $(8,2 \%)$, Ірина (7\%), Надія (6,4\%), Леся (5,8\%), Ольга, Світлана (5,3\%), Ганна (4,1\%), Тетяна, Мирослава $(1,8 \%)$, Вікторія, Зоряна, Руслана, Віра $(1,2 \%)$. До одиничних жіночих імен, використовуваних у 1970 р., зараховуємо такі: Анжела, Валентина, Зеновія, Іванна, Інна, Катерина, Людмила, Маріанна, Орися, Райса.

У 1980 р. відбувається перерозподіл частотності використання жіночих імен та зміна їхніх позицій на шкалі популярності. На першому місці тепер фіксуємо онім Наталія (17,5\%), який у попередньому періоді посідав лише п'яту позицію. Онім Галина, хоч і втратив $0,7 \%$, проте піднявся на щабель вище та опинився на другому місці, яке він поділяє з іменем Надія з такими самими відсотками $(9,2 \%)$. Як бачимо, популярність останнього зросла на $2,8 \%$. Третє місце посідають оніми Марія та Ірина (8,3\%), перший втратив 2,8\% і змістився на позицію нижче, а другий додав 1,3\% та піднявся на кілька щаблів. Найпопулярніше в попередньому періоді ім'я Оксана втратило 7,2\% та разом з іменем Леся посідає четверту позицію, обидва імені мають по 5,8\%. До частотних у розгляданий період уналежнюємо також оніми Ольга (4,2\%), Людмила, Тетяна (3,3\%), Мирослава (2,5\%), Вікторія, Юлія, Любов, Інна, Світлана, Олена, Валентина (1,7\%). Причому деякі 3 них - Людмила, Юлія, Інна, Олена, Валентина -у 1970 р. були рідковживаними. Натомість частотні в попередній період оніми Ганна, Зоряна, Руслана і Вipa змістилися до низки рідковживаних імен. Крім названих, у 1980 р. в Радехівському районі зафіксовані ще й такі одинично вживані імена: Алла, Валентина, Василина, Емілія, Маргарита, Лариса, Олеся (варіант імені Леся), Павла, Уляна, Христина, Ярослава.
У 1990 р. ситуація 3 іменуванням народжених дівчаток знову змінюється. Онім Наталія утримує свою першість на шкалі популярності 9,3\%, із таким самим відсотком повертається на перше місце найпопулярніше в 1970 р. жіноче ім'я Оксана. Так само на друге місце повертається ім'я Марія (7,6\%). Стають модними рідковживані раніше імена Василина й Мар'яна $(6,8 \%)$, Христина (5,9\%); перші два посідають третю сходинку, а третє - четверту. Крім названих, частотними жіночими іменами в цей період зафіксовані: Ольга $(5,1 \%)$, яке протягом трьох періодів зберігає свою популярність майже на одному рівні (5,3\% в 1970 p., 4,2\% в 1980 р., 5,1\% в 1990 р.); повертають свою популярність імена Ганна (4,1\% в 1970 р., $4,2 \%$ в 1990 р.) та Bipa (1,2\% в 1970 р., 1,7\% в 1990 р.); залишаються популярними імена Надія (6,4\% в 1970 р., 9,2\% в 1980 р., 4,2\% в 1990 р.), Ірина (7\% в 1970 р., 8,3\% в 1980 р., 3,4\% в 1990 p.), Вікторія (1,2\% в 1970 р., 1,7\% в 1980 р., 2,5\% в 1990 р.), Світлана (5,3\% в 1970 р., 1,7\% в 1980 р. i 1990 р.); набирають популярності оніми Юлія та Олена $(1,7 \%$ в 1980 р., 4,2 \% в 1990 р.); часто використовуваними стають рідковживані протягом двох попередніх періодів імена Катерина (2,5\%), Іванна та Адріана (1,7\%); досить поширене в попередні періоди ім'я Леся зазнає фонетичних змін і набуває форми Олеся $(3,4 \%)$; онім Галина, залишаючись серед частотних, у 1990 р. значно втратив свою популярність порівняно 3 попередніми двома періодами $(9,9 \%$ в 1970 р., 9,2\% в 1980 р., $1,7 \%$ в 1990 р.). Як одиничні в цей період фіксуємо імена: Богдана, Злата, Зоряна, Свгенія, Інна, Леся, Любов, Маріанна, Орислава, Роксолана, Руслана, Соломія, Софія, Тетяна.

У 2000 р. зберігають свою популярність імена Марія (11\%) та Наталія (8,8\%), які утримують перше і третє місця, як і в попередньому періоді. Пріоритетними жіночими іменами стають рідковживані в попередні три періоди оніми Діана $(9,9 \%$, посідає друге місце на шкалі популярності), Соломія (4,4\%), Марта та Анастасія (3,3\%), Дарія і Роксолана (2,2\%). Зберігають свою популярність імена Ірина (7\% в 1970 р., 8,3\% в 1980 р., 3,4\% в 1990 р., 7,8\% у 2000 р.), Ольга (5,3\% в 1970 р., $4,2 \%$ в 1980 p., $5,1 \%$ в 1990 p., 5,5\% у 2000 р.), Олеся (3,4\% в 1990 р., 3,3\% у 2000 р.), Катерина $(2,5 \%$ в 1990 р., 3,3\% у 2000 р.), Іванна $(1,7 \%$ в 1990 р., 2,2\% у 2000 р.). Стабільно зростає частотність використання імен Вікторія $(1,2 \%$ в 1970 p., $1,7 \%$ в 1980 p., 2,5\% в 1990 p., $5,5 \%$ у 2000 р.), Юлія (1,7\% в 1980 р., 4,2\% в 1990 р., 4,4\% у 2000 р.). Знову стають модними оніми Тетяна $(1,8 \%$ в 1970 p., $3,3 \%$ в 1980 p., 4,4\% у 2000 p.) i Людмила (3,3\% в 1980 р., 2,2\% у 2000 р.). Натомість онім Христина, залишаючись серед частотних, значно втратив у своїй популярності 
(5,9\% в 1990 р., 2,2\% у 2000 р.). До поодиноких імен цього періоду вналежнюємо такі: Аліна, Вероніка, Віра, Зоряна, Іванна, Ілона, Каріна, Лілія, Олена, Орися, Сніжана, Уляна, Яна.

У 2010 р. продовжує зростати популярність імен Вікторія та Анастасія (вони тепер піднімаються на першу позицію - 7,6\%), Тетяна (друге місце 6,3\%). 3 таким самим відсотком на другому місці фіксуємо раніше рідковживаний онім Яна. Третю сходинку посідають імена Вероніка, Дарина, Марія, Марта, Олена, Соломія, Христина, Юлія (3,8\%), а на четвертому місці - оніми Аліна, Анна, Валентина, Ірина, Наталія, Оксана, Олеся (2,5\%). Причому онім Марта, який увійшов до низки частотних лише у 2000 р., продовжує набирати популярності (3,8\% у 2010 р. проти 3,3\% у 2000 р.), повертаються до частовживаних популярне в 1970-1990 pp. імена Оксана (14,0\% в 1970 р., 5,8\% в 1980 р., 9,3\% в 1990 р., 2,5\% у 2010 р.) та Олена $(1,7 \%$ в 1980 р., 4,2\% в 1990 р., 3,8\% у 2010 р.). Зберігають свою популярність імена Олеся (3,4\% в 1990 р., 3,3\% в 2000 р., 2,5\% у 2010 р.), Соломія (4,4\% в 2000 р., 3,8\% у 2010 р.), Христина $(5,9 \%$ в 1990 р., 2,2\% в 2000 р., 3,8\% у 2010 р.), Юлія $(1,7 \%$ в 1980 p., 4,2\% в 1990 p., 4,4\% у 2000 p., $3,8 \%$ у 2010 р.). Натомість падає частотність використання онімів Марія (3,8\% у 2010 р. проти $11,1 \%$ в 1970 p., 8,3\% в 1980 p., 7,6\% в 1990 р., $11,0 \%$ у 2000 р.), Наталія (2,5\% у 2010 р. проти $8,2 \%$ в 1970 p., $17,5 \%$ в 1980 p., 9,3\% в 1990 p., $8,8 \%$ у 2000 р.), Ірина (2,5\% у 2010 р. проти 7,0\% в 1970 p., 8,3\% в 1980 p., 3,4\% в 1990 p., 7,8\% у 2000 р.). Стають частотними рідковживані в попередні періоди імена Валентина, Аліна, Вероніка. Частотне в 1970 р. та в 1990 р. ім'я Ганна знову стає популярним, але змінює свою форму на Анна, онім Дарія, що став частотним у 2000 р., змінюе свою форму на звичнішу для українців Дарина. Як поодинокі трапляються також жіночі імена Альбіна, Анна-Марія, Василина, Віталіна, Владислава, Діана, Сва, Ілона, Інна, Лідія, Лілія, Мілена, Олександра, Роксолана, Софія, Таїсія, Уляна, Ярина (похідне від Ірина). Відзначимо, що використання подвійного імені Анна-Марія, яке є найпопулярнішим 3-поміж подвійних імен в Україні, простежуємо лише у 2010 р. Як зазначає Міністерство юстиції України, подвійним іменем українці часто «прикрашали» дівчат.

У 2020 р. в Радехівському районі було зафіксовано такі жіночі імена: Анастасія, Ангеліна, Анна, Валерія, Вероніка, Вікторія, Дарина, Емілія, Ірина, Маргарита, Мілена, Оксана, Соломія, Христина, Юлія, Юстина, Яна. У цьому році деякі батьки назвали своїх дівчаток незвичними для українців іменами - Адріана, Аеліна, Аріна, Домініка, Емілі, Еріка. Ці імена вносять цікаве розмаїття в антропонімікон району.
Отже, впродовж 1970-2020 pр. у найменуванні народжених дівчаток помітне повернення українців до своїх традицій та звичаїв. У жіночому іменнико́ві Радехівського району більшість становлять українські традиційні імена, які активно функціонували впродовж століття. Це дає підстави говорити про власне український іменник району. До найуживаніших жіночих імен уналежнюємо такі: Оксана, Марія, Наталія, Ірина, Вікторія. Рідковживаних жіночих імен небагато, до них зараховуємо такі як Зеновія, Маргарита, Paїса, Tаїсія. Зафіксовано вживання старослов'янських жіночих імен Зоряна, Людмила, Орислава. Трапляються слов'янські жіночі імена, які походять від чоловічих: Мирослава, що має слов'янські корені та $є$ жіночою формою чоловічого імені Мирослав, Ярослава - жіночий варіант імені Ярослав. 3 початку XXI ст. значно покращується позиція старих канонічних імен, як-от: Анастасія, Дарія, Марія. Ю. Карпенко називає цю особливість основною тенденцією розвитку сучасного загальноукраїнського іменника [11, с. 18].

Вибираючи імена для дівчат, батьки найчастіше керуються не стільки релігійними установами чи родинними традиціями, скільки модою, «в якій виявляється суспільний, а не індивідуальний смак» [12, с. 18]. Це зумовлює швидшу зміну лідерів жіночого іменника порівняно 3 чоловічим.

Стабільне функціонування одних канонічних імен і повернення до вжитку інших нині зумовлене дією двох чинників - традиції та моди. На думку П. Чучки, родинні традиції «за ступенем актуальності в наші дні, а великою мірою і в минулі десятиліття, ... треба поставити на перше місце» [5, с. 48]. Найтиповішим виявом цього чинника слід вважати найменування новонароджених на честь прабабусь, бабусь, матерів та інших шанованих членів родини. Цей мотив утримує на провідних позиціях в іменнику́ оніми Ганна, Галина, Марія, Наталія, Надія, Оксана, Любов, Ірина, Ольга, Леся.

Стрімке зростання популярності імен Аліна, Вікторія, Діана, Соломія та Юлія зумовлене антропонімійною модою. Механізм дії цього чинника іноді пояснити нелегко. «Як і всяка мода, мода в надаванні імен $є$ досить примхливою, і не завжди вдається встановити іiі рушійні сили» [13, с. 39].

Викладений матеріал дає підстави стверджувати, що жіночий іменник більш схильний до змін, ніж чоловічий. Його межі розширюються за рахунок як давніх слов'янських композитів, так й імен західного штибу.

Вивчення часової динаміки особових імен мешканців Радехівського району Львівської області дає змогу не лише констатувати своєрідність та національну самобутність іменника́, а й виявити всю складність функціонування особових імен в антропонімійній системі. 
Висновки. Суцільне дослідження особових імен Радехівського району Львівської області, що охоплює доволі тривалий період (1970-2020 рр.), висвітлює загальні закономірності іменної динаміки й основні тенденції розвитку досліджуваної антропосистеми. Результати дослідження свідчать, що в українських системах діють як загальні тенденції розвитку іменникі́в, як-от різка зміна частотності імен i якісного складу іменникі́в у періоди, пов'язані зі зміною суспільно-політичного устрою, так і суто специфічні для обстежуваного часу й території.

Антропонімікон Радехівського району Львівської області з 1970 р. до 2000 р. демонструє відносну консервативність у виборі імен для народжених хлопчиків і дівчаток та своєрідну прерогативу, що надавалася деяким іменам у ті чи ті десятиріччя. Для цих десятирічь характерний постійний і компактний набір онімів, що складається виключно $з$ традиційних, рекомендованих церковними святцями календарних імен, а також значна їх концентрація. Основні позиції в рейтингові популярності посідають чоловічі імена Володимир, Василь, Андрій та жіночі імена Оксана, Марія, Наталія.

У XXI ст. ситуація вибору імен змінилася. Відміна обов'язковості церковних святців негайно позначилася на архаїзації значної частини онімів, що стали непопулярними. Зрештою, отримавши свободу у виборі імен для своїх дітей, найменувачі спричинили цілу антропонімійну повінь. До найяскравіших новин в антропонімії цього часу, безперечно, належать численні запозичення, багатокомпонентні лексеми, що набули документальної сили.

Динаміка сучасного українського іменника́ потребує фронтального дослідження, оскільки дуже важливо виявити причини й тенденції, що зумовлюють динаміку особових імен на різних хронологічних зрізах, що й становитиме перспективу подальших досліджень.

\section{ЛІТЕРАТУРА}

1. Франко І.Я. Зібрання творів у 50 т. Київ : Наукова думка, 1982. Т. 36.488 с.

2. Свистун Н.О. Особові імена як знаки ідентифікації та індивідуалізації особи: теорія досліджень. Наукові записки Національного університету «Острозька академія». Серія «Філологічна». 2016. Вип. 61. С. 128-130.

3. Хигир Б.Ю. Язык тела, имени и даты рождения, или Популярная психология и физиогномика. Москва : Астрель, 2010. 619 с.

4. Флоренский П.А. Имена. Москва : ЭКСМО-Пресс ; Харьков : Фолио,1998. 912 с.

5. Чучка П.П. Антропонімія Закарпаття. Ужгород : УжДУ, 2008. 672 с.

6. Брайченко С.Л. Непопулярні чоловічі особові імена мешканців Одещини. Наукові записки Національного університету «Острозька академія». Серія : Філологічна. 2016. Вип. 60. С. 19-21.

7. Антоненко-Давидович Б. Як ми говоримо і як треба говорити. Нью-Йорк ; Філадельфія, 1980. 241 с.

8. Суперанская А.В. Структура имени собственного. Фонология и морфология. Москва : Наука, 1969. $207 \mathrm{c}$.

9. Белецкий А.А. Лексикология и теория языкознания : (ономастика). Киев : Изд-во Киев. ун-та, 1972. $209 \mathrm{c.}$

10. Скорук І.Д. Динаміка антропонімікону м. Луцька в XX ст. : дис. ... канд. філол. наук : 10.02 .01 ; НАН України ; Інститут української мови. Київ, 1999. 180 с.

11. Карпенко Ю.О. Динаміка українських особових імен. Науковий вісник Чернівецького університету. Слов'янська філологія. Чернівці : Рута, 2007. Вип. 356-359. С. 285-289.

12. Буга Т.В. Динаміка частотного десятка жіночих імен Донеччини впродовж 1890-2000-х років. Актуальні проблеми філології та перекладознавстві. 2013. Вип. 6 (1). С. 11-21.

13. Чучка П.П. Антропонімія Закарпаття (Вступ та імена) : конспект лекцій. Ужгород : Вид-во Ужгород. ун-ту, 1970. $101 \mathrm{c}$.

\section{REFERENCES}

1. Franko, I.Ia. (1982). Zibrannia tvoriv u $50 \mathrm{tt}$. [The collected works are in 50 vol.] Vol. 36. Kyiv : Naukova dumka. 488 p.

2. Svystun, N.O. (2016). Osobovi imena yak znaky identyfikatsii ta indyvidualizatsii osoby: teoriia doslidzhen [Personal names as signs of identification and individualization of the person: research theory]. Scientific notes of the National University "Ostroh Academy". Series "Philological". Issue 61. Pp. 128-130.

3. Khyhyr, B.Iu. (2010). Yazyk tela, ymeny y daty rozhdenyia, yly Populiarnaia psykholohyia y fyzyohnomyka [Language of the body, name and date of birth, or Popular psychology and physiognomy]. Moscow : Astrel. $619 \mathrm{p}$.

4. Florenskyi, P.A. (1998). Ymena [Names]. Moscow: EXMO-Press, Kharkiv : Folis. 912 p.

5. Chuchka, P.P. (2008). Antroponimiia Zakarpattia [Anthroponymy of Transcarpathia]. Uzhhorod: UzhDU. 672 p. 
6. Braichenko, S.L. (2016). Nepopuliarni cholovichi osobovi imena meshkantsiv Odeshchyny [Unpopular male personal names of the inhabitants of Odessa region]. Scientific notes of the National University "Ostroh Academy". Series: Philological, Issue 60. Pp. 19-21.

7. Antonenko-Davydovych, B. (1980). Yak my hovorymo i yak treba hovoryty [How we speak and how to speak]. New York, Philadelphia. 241 p.

8. Superanskaia, A.V. (1969). Struktura ymeny sobstvennoho. Fonologiya i morfologiya [The structure of the proper name. Phonology and morphology]. Moscow : Nauka. 207 p.

9. Beletskyi, A.A. (1972). Leksykolohyia y teoryia yazykoznanyia : (onomastyka) [Lexicology and theory of linguistics: (onomastics)]. Kiev: Izdatel'stvo Kiyevskogo universiteta. 209 p.

10. Skoruk, I.D. (1999). Dynamika antroponimikonu m. Lutska $v$ XX st. [Dynamics of the anthroponymicon of Lutsk in the XX century] : dis. ... cand. philol. nauk : 10.02.01 / NAN Ukrayiny; Instytut ukrayinskoyi movy. Kyiv. 180 p.

11. Karpenko, Yu.O. (2007). Dynamika ukrainskykh osobovykh imen [Dynamics of Ukrainian personal names]. Scientific Bulletin of Chernivtsi University. Slavic philology. Issue 356-359. Chernivtsi : Ruta. Pp. 285-289.

12. Buha, T.V. (2013). Dynamika chastotnoho desiatka zhinochykh imen Donechchyny vprodovzh 1890-2000-kh rokiv [Dynamics of the frequency ten female names of Donetsk region during the 1890-2000]. Actual problems of philology and translation studies. Issue 6 (1). Pp. 11-21.

13. Chuchka, P.P. (1970). Antroponimiia Zakarpattia (Vstup ta imena) : konspekt lektsii [Anthroponymy of Transcarpathia (Introduction and names): lecture notes]. Uzhhorod : Vydavnytstvo Uzhhorods'koho universytetu. $101 \mathrm{p}$. 